\title{
PENERAPAN POLA ORANG TUA ASUH TERHADAP REMAJA PUTUS SEKOLAH DI PANTI SOSIAL BINA REMAJA (PSBR) BAMBU APUS JAKARTA TIMUR
}

\author{
Maygie Priayudana \\ Pendamping Program Keluarga Harapan (PKH) Kota Depok \\ Email: mpriayudana@hmail.com
}

Received: $2^{\text {th }}$ March 2018; Revised: $5^{\text {th }}$ April 2018; Accepted: $19^{\text {th }}$ June $_{2018}$

\begin{abstract}
Teenagers or adolescents are perceived as an investment and accordingly seen as a potential for the welfare and nation assets in the future by parents. It is important to produce generation serving as the backbone of a nation need an early preparation by the parents through fulfillment of physical, mental and social needs in accordance with growth period. As an institution responsible for the problems of a dropping out teenage, PSBR Bambu Apus of East Jakarta is in charge of providing a professional social services for a drop-outs cases. In cooperation with other social institutions, PSBR provides a holistic guidance and services by using different care systems such as dormitories as residence and socialization of beneficiaries through foster parents. This research is a qualitative study providing an overview of how the implementation of foster parent patterns for a drop out teenagers.
\end{abstract}

Keywords: foster parents, teenager, foster home, drop out.

Abstrak. Anak atau remaja merupakan investasi bagi orang tua, bahkan merupakan potensi kesejahteraan serta aset bangsa di masa depan. Untuk mencetakgenerasiyang kelak dapat menjadi tulang punggung bangsanya harus dipersiapkan sejak dini oleh orang tua melalui pemenuhan kebutuhan baik fisik, mental maupun sosial yang sesuai dengan masa tumbuh kembangnya, menjadi penting. Sebagai instansi yang bertanggung jawab terhadap permasalahan remaja putus sekolah terlantar, PSBR Bambu Apus Jakarta Timur bertugas memberikan pelayanan sosial secara profesional bagi remaja putus sekolah terlantar. PSBR melakukan bimbingan dan pelayanan yang bersifat holistik dengan menggunakan sistem asuhan yang berbeda dengan sistem di panti sosial lain yang menggunakan asrama sebagai tempat tinggal dan tempat sosialisasi para penerima manfaat yaitu melalui orang tua asuh. Oleh karena itu, penulis melakukan penelitian kualitatifyang akan memberikan gambaran bagaimana penerapan pola orang tua asuh terhadap remaja putus sekolah.

Kata kunci: orang tua asuh, remaja, panti. 


\section{Pendahuluan}

Salah satu hak yang harus dipenuhi orang tua adalah hak akan pendidikan bagi anak. Dengan terpenuhinya hak tersebut, anak dapat mengembangkan potensi-potensi dan bakat yang ada pada dirinya dan dapat bertumbuhkembang secara baik. Sayangnya, kondisi ekonomi masyarakat yang berbeda-beda membuat tidak semua keluarga memiliki kemampuan ekonomi yang memadai. Mereka tidak mampu memenuhi segala kebutuhan anaknya. Keluarga dengan status sosial ekonomi menengah ke bawah harus merogoh kantong lebih dalam untuk memenuhi kebutuhan keluarga, termasuk dalam pemenuhan hak anak akan pendidikan. Ditambah dengan tingginya biaya pendidikan, semakin banyak keluarga yang tidak mampu membiayai sekolah sehingga akhirnya sang anak terpaksa mengalami putus sekolah.

Menurut Wahono (1995), penyebab mendasar anak putus sekolah bukan akibat kurangnya kesadaran pentingnya pendidikan, tapi akibat faktor ekonomi. Dengan kata lain, terdapat kaitan erat antara beban ekonomi masyarakat dengan kegiatan pendidikan anak. Kesulitan finansial seringkali membuat anak-anak harus membantu ekonomi keluarga. Hingga akhirnya pendidikan mereka terbengkalai, bahkan mengalami putus sekolah.

Putus sekolah adalah proses berhentinya siswa secara terpaksa dari suatu lembaga pendidikan tempat dia belajar. Putus sekolah yang dimaksud di sini adalah terlantarnya anak dari sebuah lembaga pendidikan formal disebabkan oleh berbagai faktor. Jumlah anak putus sekolah di Indonesia meningkat dengan pesat pada tahun 2011 dibandingkan tahum 2010. Menurut United Nations Educational, Scientific and Cultural Organization (UNESCO), data terbaru menunjukkan bahwa 260,000 anak Indonesia putus sekolah tahun 2011, peningkatan yang tajam dibandingkan angka 160,000 pada tahun 2010 (ACDP INDONESIA, 2013).

Menurut Agoes Dariyo (2004) ketika seorang anak memasuki usia remaja, anak mengalami peningkatan emosional yang terjadi secara cepat. Pada masa remaja awal, dikenal sebagai masa strom and stress: remaja memiliki keinginan bebas untuk menentukan nasib sendiri. Kalau terarah dengan baik, mereka akan menjadi individu yang memiliki rasa tanggung jawab. Tetapi kalau tidak, mereka bisa menjadi orang yang tak memiliki masa depan yang baik.

Ketika mereka mengalami putus sekolah maka mereka menjadi tidak terarah dengan baik. Akibatnya muncul berbagai masalah seperti terlibat dalam kenakalan remaja, tawuran, minum-minuman dan perkelahian, menjadi anak jalanan serta timbulnya perasaan minder dan rendah diri. Ketiadaan waktu khusus untuk mengikuti 
kegiatan belajar di sekolah membuat remaja putus sekolah lebih rentan masuk ke dalam pergaulan bebas. Mereka juga cenderung mudah terlibat interaksi dengan siapa saja, bahkan mungkin dengan pecandu narkoba. Ketiadaan aturan dan kesepakatan membuat remaja putus sekolah tidak lagi mau menerima masukan apapun, pulang semaunya, terlampau sering bermain, dan cenderung tidak memperhatikan norma kesusilaan dan norma agama. Tidak hanya itu, putus sekolah juga membuka 'kran' pengangguran dan menutup masa depan yang cerah bagi mereka yang mengalaminya (St Wardah Hanafie Das dan Abdul Halik, 2013).

Sebagaimana aspek-aspek psikologis lainnya, kemandirian juga bukanlah murni sebuah bawaan semata yang melekat pada individu sejak ia dilahirkan ke dunia, perkembangannya juga dipengaruhi oleh sejumlah faktor sebagai berikut:

1. Gen atau keturunan orang tua

Orang tua yang memiliki sifat kemandirian tinggi seringkali menurunkan anak yang memiliki kemandirian juga. Namun ada juga yang berpendapat sesungguhnya bukan sifat kemandirian orang tuanya yang menurun pada anaknya, melainkan sifat orang tuanya yang muncul bersamaan dengan cara orang tuanya mendidik.

2. Pola asuh orang tua

Orang tua yang terlalu banyak melarang dan mengeluarkan kata "jangan" kepada anak tanpa disertai penjelasan yang rasional akan menghambat perkembangan kemandirian anak. Sebaliknya, orang tua yang menciptakan suasana aman dalam interaksi keluarganya akan mendorong kelancaran perkembangan motorik sang anak.

3. Sistem pendidikan di sekolah

Proses pendidikan yang lebih menekankan pentingnya penghargaan terhadap potensi anak, pemberian reward dan penciptaan kompetisi yang positif akan memperlancar kemandirian remaja.

4. Sistem kehidupan bermasyarakat

Lingkungan yang aman, menghargai ekspektasi potensi remaja dalam membentuk kegiatan dan tidak berlaku hierarkis akan merangsang dan mendorong perkembangan kemandirian remaja.

Melihat dari faktor-faktor di atas, dapat dilihat bahwa pola asuh orang tua memiliki peran penting dalam kemandirian anak, apalagi mengingat anak tersebut putus sekolah sehingga faktor sekolah tidak dapat digunakan untuk membantu perkembangan kemandirian anak. 
Berdasarkan pemaparan di atas, dapat dipahami bahwa remaja yang mengalami putus sekolah atau terlantar perlu mendapat perhatian dan penanganan. Menurut pasal 9 ayat 1 UU 23/2002 tentang Perlindungan Anak, "Setiap anak berhak memperoleh pendidikan dan pengajaran dalam rangka pengembangan pribadinya dan tingkat kecerdasannya sesuai dengan minat dan bakatnya".

Remaja putus sekolah terlantar membutuhkan penanganan dan pelayanan sosial agar dapat mencapai kesejahteraan. Kesejahteraan anak berdasarkan pasal 1 ayat 1 poin a (UU 4/1979 tentang Kesejahteraan Anak) adalah "suatu tata kehidupan dan penghidupan anak yang dapat menjamin pertumbuhan dan perkembangannya dengan wajar baik secara jasmani, rohani maupun sosial".

Selain membantu pemenuhan kebutuhan baik dari segi fisik, mental dan sosial, bentuk perhatian yang juga diperlukan remaja putus sekolah adalah mendapatkan pengasuhan, perlindungan dan pendidikan sebagaimana hak yang dimiliki seorang anak. Dengan mendapatkan pendidikan dan pengasuhan yang baik, para remaja tersebut diharapkan dapat bersikap dan berperilaku positif serta menjadi pribadi mandiri.

Sebagai instansi yang bertanggung jawab terhadap permasalahan remaja putus sekolah terlantar adalah Kementerian Sosial RI yang berada di bawah dan bertanggung jawab langsung kepada Direktorat Jenderal Pelayanan dan Rehabilitasi Sosial. PSBR bertugas memberikan pelayanan sosial secara profesional bagi remaja putus sekolah terlantar. Tujuan dari pelayanan sosial ini adalah agar mereka memiliki kemampuan dan kemandirian, serta dapat berkembang secara wajar di tengah masyarakat sehingga mereka dapat terampil dan aktif berpartisipasi dalam pembangunan (Profil PSBR Jakarta Timur).

Dengan visi “Terwujudnya Kemandirian Remaja”, PSBR Bambu Apus memberikan bimbingan dan pelayanan bersifat preventif, rehabilitatif dan promotif dalam bentuk bimbingan fisik, mental, sosial, pelatihan keterampilan, resosialisasi serta bimbingan lanjut bagi remaja terlantar putus sekolah agar mampu mandiri dan berperan aktif dalam kehidupan bermasyarakat. PSBR juga memfasilitasi penerima manfaatyang ingin ikut sekolah kejar paket SLTP dan SLTA agar dapat sekolah kembali dan mendapatkan ijazah sebagai modal untuk melamar pekerjaan.

PSBR melakukan bimbingan dan pelayanan yang bersifat holistik dengan menggunakan sistem asuhan keluarga berbeda dengan sistem di panti sosial lain yang menggunakan asrama sebagai tempat tinggal dan tempat sosialisasi para penerima manfaat. Dengan keluarga asuh, setiap penerima manfaat dikelompokkan 
dan ditempatkan dalam satu rumah asuh yang terdiri dari orang tua asuh dan anakanaknya. Mereka membaur sebagaimana layaknya anak dengan orang tuanya sendiri. Dengan demikian, orang tua asuh ini diharapkan dapat memberikan arahan dan bimbingan kepada remaja agar menjadi remaja yang mandiri.

Dari sisi remaja penerima manfaat, mereka diharapkan dapat mengikuti pembinaan dengan baik. Penekanan yang dilakukan oleh lembaga PSBR bagi penerima manfaat adalah adanya perubahan sikap dan perilaku bagi remaja agar menjadi mandiri. Kemandirian itu sendiri merupakan salah satu tugas perkembangan remaja sehingga kegagalan dalam usaha mencapai kemandirian akan menimbulkan kesulitan dalam sebagian besar bidang kehidupan. Dengan kata lain, untuk menjadi dewasa, kematangan fisik saja tidaklah cukup, seorang remaja harus matang secara sosial, salah satunya memiliki perilaku mandiri (Yuni Rizkiani, 2007). Setelah keluarga dari lembaga, remaja atau penerima manfaat diharapkan dapat bersikap lebih baik agar dapat diterima oleh masyarakat, dapat tumbuh dan berkembang secara wajar, serta dapat melaksanakan fungsinya sebagai anggota masyarakat yang mandiri, aktif dan produktif.

\section{Metode}

Penelitian ini menggunakan penelitian kualitatif yang bertujuan untuk memberikan gambaran. Menurut Lofland (dalam Irawan Soehartono, 2004) sumber data utama penelitian kualitatif ialah kata-kata, dan tindakan. Selebihnya adalah data tambahan seperti dokumen dan lain-lain. Kata-kata dan tindakan orang-orang diamati atau diwawancarai merupakan sumber data utama. Sumber data utama dicatat melalui catatan tertulis atau melalui perekaman video/audio tapes, pengambilan foto atau film. Pencatatan sumber data utama melalui wawancara atau pengamatan berperan serta merupakan hasil usaha gabungan dari kegiatan melihat, mendengar dan bertanya.

\section{Pengertian Pola Asuh}

Menurut Singgih D. Gunarsa (2000), pola asuh adalah gambaran yang dipakai oleh orang tua untuk mengasuh (merawat, menjaga atau mendidik) anak. Pola asuh orang tua yaitu tindakan atau sikap orang tua dalam berinteraksi dengan anaknya. Pengasuhan orang tua diharapkan dalam memberikan kedisiplinan anak, memberikan tanggapan yang sebenarnya agar anak merasa orang tuanya selalu meberikan perhatian yang positif terhadapnya.

Sebelum pembahasan lebih dalam, ada baiknya kita mengetahui terlebih dahulu 
jenis-jenis pola pengasuhan orang tua atas anak. Menurut Diana Baumrind (dalam Santrock, 2007) ada 4 jenis pola pengasuhan orang tua, yaitu:

\section{a. Pengasuhan Otoritarian (Authoritarian Parenting)}

Pengasuhan otoritarian ini adalah pola yang membatasi dan menghukum. Orang tua mendesak anak untuk mengikuti arahan dan menghormati pekerjaan dan upaya mereka. Batas dan kendali yang tegas diterapkan pada anak, dan sangat sedikit tawar menawar verbal yang diperbolehkan. Pola ini bisa mengakibatkan perilaku anak yang tidak kompeten secara sosial. Anak dengan orang tua otoriter seringkali tidak bahagia, takut, minder ketika membandingkan diri dengan orang lain, tidak mampu memulai aktivitas, dan memiliki kemampuan komunikasi yang lemah. Anak dari orang tua yang otoriter mungkin berperilaku agresif.

\section{b. Pengasuhan Otoritatif (Authoritatif Parenting)}

Pola ini mendorong anak untuk mandiri, namun masih menempatkan batas dan kendali pada tindakan mereka. Tindakan verbal memberi dan menerima dimungkinkan, dan orang tua bersikap hangat dan penyayang terhadap anak. Pola ini biasanya mengakibatkan perilaku anak kompeten secara sosial. Anak yang memiliki orang tua otoritatif sering kali ceria, bisa mengendalikan diri dan mandiri dan berorientasi pada prestasi. Mereka cenderung mempertahankan hubungan yang ramah dengan teman sebaya, bekerja sama dengan orang dewasa, dan bisa mengatasi stress dengan baik.

\section{c. Pengasuhan yang Mengabaikan (Neglectful Parenting)}

Pola di mana orang tua sangat tidak terlibat dalam kehidupan anak. Anak dengan orang tua yang seperti ini merasa bahwa aspek lain kehidupan orang tua lebih penting daripada diri mereka. Anak-anak ini cenderung tidak memiliki kemampuan sosial dan banyak di antaranya memiliki kemampuan pengendalian diri yang buruk.

\section{d. Pengasuhan yang Menuruti (Indulgent Parenting)}

Suatu pola di mana orang tua sangat terlibat penuh dengan anak tetapi tidak menaruh banyak tuntutan dan kontrol yang ketat pada mereka. Hasilnya, anak tidak pernah belajar mengendalikan perilakunya sendiri dan selalu berharap mendapatkan keinginannya. Anak yang memiliki orang tua yang selalu menuruti jarang belajar menghormati orang lain dan mengalami kesulitan untuk mengendalikan perilakunya. Mereka mungkin mendominasi, egois, tidak menuruti aturan dan kesulitan dalam hubungan dengan teman sebaya. 
Setelah mengenal jenis-jenis dari pola pengasuhan, terdapat indikator pola asuh terhadap anaknya yang dapat dikelompokkan sebagai berikut:

a. Pola Asuh yang Menuruti (Indulgent Parenting), antara lain memiliki indikator:

1. Memberikan kebebasan kepada anak tanpa ada batasan dan aturan dari orang tua

2. Anak tidak mendapatkan hadiah atau pun pujian meski anak berperilaku sosial yang baik

3. Anak tidak mendapatkan hukuman meski anak melanggar aturan

4. Orang tua kurang kontrol terhadap perilaku dan kegiatan anak seharihari

5. Orang tua hanya berperan sebagai pemberi fasilitas

b. Pola Asuh otoritarian (Authoritarian Parenting), indikatornya adalah

1. Orang tua menerapkan peraturan yang ketat

2. Tidak adanya kesempatan untuk mengemukakan pendapat

3. Segala peraturan yang dibuat harus dipatuhi oleh anak

4. Berorientasi pada hukuman (fisik maupun verbal)

5. Orang tua jarang memberikan hadiah ataupun pujian

c. Pola Asuh otoritatif (Authoritatif Parenting) mempunyai indikator:

1. Adanya kesempatan bagi anak untuk berpendapat

2. Hukuman diberikan akibat perilaku salah

3. Memberikan pujian ataupun hadiah kepada perilaku yang benar

4. Orang tua membimbing dan mengarahkan tanpa memaksakan kehendak kepada anak

5. Orang tua memberikan penjelasan secara rasional jika pendapat anak tidak sesuai

6. Orang tua mempunyai pandangan masa depan yang jelas terhadap anak.

\section{Pola Pengasuhan yang Diterapkan}

PSBR Bambu Apus Jakarta Timur memiliki pola pengasuhan yang berbeda dengan kebanyakan panti lainnya. PSBR Bambu Apus ini menerapkan sistem keluarga asuh, sehingga si anak panti (penerima manfaat) ini tidak tinggal di panti melainkan bersama dengan keluarga asuh mereka. Di mana setiap rumah asuh terdapat orang tua asuh dengan sistem pengasuhan adalah menganggap anak seperti keluarganya 
sendiri, mengayomi anak. Orang tua asuh dapat menjadi teman, sahabat, guru bagi para penerima manfaat. Yang menjadi orang tua asuh adalah pegawai PSBR Bambu Apus Jakarta yang bersedia menjadi orang tua asuh.

Berdasarkan hasil wawancara dan pengamatan yang penulis lakukan kepada orang tua asuh di PSBR Bambu Apus, pada umumnya pola pengasuhan yang mendidik setiap anak untuk berperilaku baik dan mandiri. Hanya pada prakteknya setiap orang tua asuh melakukan dengan cara yang berbeda dengan pendekatan yang berbeda pula terhadap setiap anak, karena tidak ada standar pola pengasuhan yang baku. Pola asuh dalam penelitian ini yaitu pola asuh yang diberikan orang tua asuh kepada anak asuhnya dalam bentuk perlakuan fisik maupun psikis yang tercermin dalam tutur kata, sikap dan tindakan.

Dalam memberikan aturan, orang tua asuh menerapkan aturan umum yang telah diterapkan oleh pihak PSBR terhadap penerima manfaat secara konsisten atau terusmenerus. Cukup banyak aturan yang diberikan oleh orang tua asuh, seperti tidak boleh merokok, tidak boleh keluar tanpa izin orang tua asuh, pulang tidak boleh lebih dari jam 21.00 WIB. Semua dilakukan agar remaja bisa memahami makna disiplin dalam kehidupannya dan apabila remaja melanggar aturan yang telah diterapkan maka orang tua asuh akan memberikan sanksi.

Seperti yang dilakukan oleh Ibu Habibi (salah satu orang tua asuh), beliau menerapkan kedisiplinan dan ketegasan, hal ini terlihat ketika setiap anak harus membiasakan diri untuk izin. Di samping itu, beliau memberikan reward and punishment kepada setiap anak asuhnya. Ketika ada anak asuhnya yang melanggar peraturan, beliau selalu memberikan teguran. Begitu juga sebaliknya, ketika ada anak asuhnya yang berperilaku baik, sopan dan kelihatan ada perubahan dari awalnya malas menjadi rajin, beliau memberikan reward berupa pujian.

Selain itu, setiap anak asuh dididik untuk disiplin dengan harus menaati setiap peraturan yang ada dalam rangka perubahan perilaku untuk mandiri. Ketika mereka melanggar peraturan diberikan teguran dan nasehat untuk memberikan penjelasan bahwa apa yang telah dilakukannya tidak baik. Namun jika memberikan sanksi atau hukuman kepada anak asuh tidak dilakukan secara fisik karena itu tidak dibenarkan.

“...Ketika mereka melanggar peraturan yang tidak berat, anak asuh diberikan teguran dan nasehat untuk memberikan penjelasan bahwa apa yang telah dilakukannya tidak baik. Tetapi kalau untuk melanggar aturan yang berat, anak asuh diharuskan untuk membuat surat pernyataan.." (Orang Tua Asuh, Sriyanti). 
Dalam hal memahami perkembangan anak asuhnya, orang tua asuh sangat ekstra dalam memahami karakter setiap anak asuhnya dengan karakter anak yang berbeda-beda. Ada yang emosinya tinggi, sedang, bahkan masih labil. Semua ini dapat dilihat dari bahasa tubuh apabila remaja sedang ada masalah, biasanya orang tua asuh akan berusaha mencari tahu apa masalah yang sedang dihadapi.

"..Masa remaja dianggap sebagai masa badai dan stress, karena mereka telah memiliki keinginan bebas untuk menentukan nasib diri sendiri. Kalau terarah dengan baik, maka ia akan menjadi seseorang individu yang memiliki rasa tanggung jawab, tetapi kalau tidak terbimbing, maka bisa menjadi seorang yang tak memiliki masa depan yang baik. Untuk itu saya berusaha untuk memahami dan mengarahkan emosinya ini agar terarah dengan positif.." (Sriyanti).

Melalui pengamatan yang dilakukan terhadap pola pengasuhan, dalam hal ini diketahui pola pengasuhan yang diterapkan di rumah asuh terlihat adanya komunikasi dua arah antara orang tua dan anak asuh. Misalnya antara orang tua asuh selalu memberikan contoh berupa penjelasan dengan menerangkan alasan-alasan dari aturan yang dibuat sehingga anak asuh menjadi mengerti dan paham. Kemudian dalam memberikan tugas dan pekerjaan yang ada di rumah asuh, orang tua asuh tidak memberikan tugas tersebut secara langsung, tetapi anak asuh diberikan kebebasan untuk berdiskusi dengan anak asuh lainnya untuk mengerjakan tugas atau pekerjaan tersebut. Hal ini dilakukan agar anak asuh dalam mengerjakan tugas yang diberikan tidak merasa tertekan, dan hal ini di lakukan juga agar selama ini di rumah orang tua asuh dan anak asuh selalu mengedepankan sikap yang demokratis.

Tidak hanya itu, untuk mendukung perkembangan kemandirian dari anak asuh, orang tua asuh selalu melibatkan anak asuh dalam menentukan sikapnya terhadap kegiatan-kegiatan yang dilakukan di dalam rumah asuh. Di mana menurut Steinberg (Nasution, 2013), kemandirian remaja adalah usaha remaja untuk dapat menjelaskan dan melakukan sesuatu yang sesuai dengan keinginannya sendiri setelah remaja tersebut mempelajari keadaan sekelilingnya. Perubahan fisik, kognitif dan peranan merupakan bagian yang mempengaruhi perkembangan kemandirian.

Salah satu contoh yang dilakukan orang tua asuh adalah dalam memberikan tugas-tugas kepada anak asuh dengan tidak menunjuk langsung akan tetapi orang tua asuh memberikan jadwal kepada anak asuh yang kemudian menentukan sendiri untuk pembagian-pembagian jadwal serta tugas yang akan dikerjakan oleh masingmasing anak asuh. Dengan demikian, diharapkan anak asuh dapat lebih memiliki rasa 
tanggung jawab terhadap tugas yang diberikan.

“...Saya berusaha untuk melibatkan anak asuh saya ketika ada kegiatan yang harus dilakukan di rumah asuh, jadi saya tidak memaksakan kehendak saya untuk menentukan siapa saja yang harus melakukan kegiatan tersebut, tetapi itu ditentukan atas dasar kesepakatan anak asuh namun saya masih memberikan batas kepada mereka..." (Orang tua asuh, Bapak Suroso)

Dengan pola pengasuhan orang tua asuh yang terarah serta adanya peraturan yang ditaati oleh setiap penerima manfaat membuat mereka menjadi terbiasa dengan segala aturan yang ada sehingga membuat diri mereka disiplin hingga akhirnya membantu dalam mendukung perkembangan kemandiriannya. Hal ini juga diungkapkan oleh salah satu penerima manfaat atau anak asuh yaitu $A B$, dirinya mengaku bahwa setelah berada di PSBR Bambu Apus merasakan mendapatkan berbagai pengalaman dan pengajaran yang tidak didapatkan sebelumnya baik itu di rumah maupun di lingkungannya. Meskipun $\mathrm{AB}$ sempat kaget dan belum terbiasa dengan pola pengasuhan yang dilakukan orang tua asuh namun seiring berjalannya waktu AB mulai terbiasa untuk disiplin. Dengan pola pengasuhan yang diterapkan orang tua asuhnya dan adanya aturan-aturan yang harus ditaati sangat berpengaruh pada sikap dan perilaku dirinya menjadi mandiri.

Hal serupa juga disampaikan oleh ATA, semenjak tinggal di rumah asuh dirinya merasa dapat meningkatkan kemandiriannya yakni mulai dari belajar disiplin akan peraturan, tanggung jawab akan tugas rumah, tentang nilai baik dan buruk, perilaku lainnya dalam pergaulan.

“... Selama saya berada di rumah asuh, menurut saya sistem asuhan keluarga disini sangat mendukung perkembangan kemandirian saya, karena kalau di rumah sendiri saya bebas mau ngapain aja gitu, tapi kalau di sini saya berusaha untuk menuruti segala peraturan yang ada, dan itu yang membuat saya menjadi tidak bergantung pada orang tu..."

Berdasarkan pemaparan di atas penulis dapat menyimpulkan bahwa pola pengasuhan yang diterapkan oleh orang tua asuh adalah pengasuhan otoritatif. Di mana pola asuh otoritatif ditandai dengan adanya komunikasi terbuka dua arah, misalnya antara orang tua asuh dan anak asuh selalu memberikan contoh, penjelasan yang menerangkan alasan-alasan dari aturan yang dibuat sehingga anak asuh menjadi 
mengerti dan paham.

Namun hal yang disayangkan penulis adalah tidak ada standar yang baku tentang pola pengasuhan di PSBR Bambu Apus sehingga ini dapat dikatakan menjadi bahan temuan baru. Mengingat ini menjadi penting agar seluruh orang tua asuh memiliki pola pengasuhan yang sama sehingga tujuan dari perkembangan kemandirian anak putus sekolah ini menjadi dapat tercapai.

\section{Penutup}

Meski belum ada standar baku, namun penulis dapat menyimpulkan bahwa orang tua asuh di PSBR Bambu Apus Jakarta ini mencoba menerapkan pola pengasuhan otoritatif. Dengan pola pengasuhan yang bersifat otoritatif, di mana pola ini biasanya akan mengakibatkan perilaku anak yang kompeten secara sosial. Penerima manfaat atau anak asuh juga merasakan adanya pola pengasuhan otoritatif dan merasakan manfaat dari pola pengasuhan tersebut. Salah satu manfaat yang didapatkan adalah adanya perkembangan dalam kemandirian anak asuh.

Orang tua asuh sangat berperan dalam mendukung kemandirian pada remaja putus sekolah di PSBR Bambu Apus, hal ini terlihat dari hasil temuan dan wawancara. Di mana anak asuh selama berada di rumah asuh merasa bahwa orang tua asuh sangat mendukung perkembangan kemandirian. Hal ini sejalan dengan apa yang diharapkan dari PSBR Bambu Apus terhadap anak asuh yakni terwujudnya kemandirian remaja.

Berdasarkan dari ulasan di atas, maka saran yang dapat dirangkum oleh penulis adalah sebagai berikut:

1. Kepada orang tua asuh di PSBR Bambu Apus Jakarta Timur disarankan agar dapat lebih mengembangkan aspek-aspek kemandirian berupa kemandirian nilai, perilaku dan emosi. Agar remaja dalam hal ini adalah anak asuh dapat memaksimalkan perkembangan kemandiriannya sebagai salah satu solusi dari penanganan anak putus sekolah.

2. Kepada pihak PSBR Bambu Apus Jakarta Timur disarankan untuk membuat standar pola pengasuhan yang baku agar setiap orang tua asuh memiliki pola pengasuhan yang seragam sehingga dapat mendukung perkembangan kemandirian remaja.

\section{Daftar Pustaka}

Dariyo, Agoes. (2004). Psikologi Perkembangan Remaja. Bogor: Ghalia Indonesia. Gunarsa, Singgih. (2000). Psikologi Perkembangan. Jakarta: PT BPK Gunung Mulia. 
Santrock, John W. (2007). Perkembangan Anak. Jakarta: Erlangga.

Wahono. (1995). Belajar dan Faktor-faktor yang Mempengaruhinya Cet 3. Jakarta: Rineka Cipta, 1995.

Rizkiani, Yuni. (2007). Hubungan Antara Kemandirian Dengan Kemampuan Memecahkan Masalah pada Remaja. Jakarta: UIN Psikologi.

Das, St Wardah Hanafie dan Abdul Halik. Masalah Putus Sekolah dan Pengangguran Tinjauan Sosiologi Pendidikan, diakses pada 23 Oktober 2013.

Soehartono, Irawan. (2004). Metode Penelitian Sosial: Suatu Teknik Penelitian Bidang Kesejahteraan Sosial dan Ilmu Sosial Lainnya. Bandung: PT. Remaja Rosdakarya. Undang-undang Republik Indonesia Nomor 23/2002 tentang Perlindungan Anak Undang-undang Republik Indonesia Nomor 4/1979 tentang Kesejahteraan Anak 